\title{
THE EFFECTIVENESS OF LEARNING DURING A PANDEMIC COVID-19
}

\author{
Abdul Mujib \\ Institut Agama Islam Negeri (IAIN) Metro \\ Email: abdulmujib@metrouniv.ac.id \\ Yuyun Yunita \\ Institut Agama Islam Negeri (IAIN) Metro \\ Email: yuyunyunita@metrouniv.ac.id
}

\begin{abstract}
Abstrak
Masa pandemi yang mengharuskan semua orang, termasuk pelajar untuk beraktivitas di rumah saja, terasa lebih dimudahkan karena adanya kemajuan teknologi. Teknologi yang paling berpengaruh di bidang pendidikan saat ini adalah Internet. Internet memungkinkan para pengajar untuk memberikan materi pembelajaran tanpa harus bertemu langsung. Pengajar dapat menguggah materi pembelajaran untuk kemudian diakses oleh para pelajar. Beberapa aplikasi dan situs berbasis internet juga biasa digunakan oleh pengajar dan pelajar untuk mengadakan kelas tatap muka melalui video call Whatsapp, Google Clasroom, Zoom Meeting dan media online lainnya. Selain untuk dalam kegiatan belajar mengajar, teknologi berbasis internet juga dapat dimanfaatkan untuk menunjang kegiatan produktif mahasiswa. Dikarenakan adanya kebijakan work from home ini, kegiatan kesiswaan seperti organisasi, kepanitiaan, klub dan lain sebagainya menjadi terhambat. Namun, dengan memanfaatkan aplikasi dan situs berbasis internet seperti Google Meet, Zoom, Skype dan lain sebagainya, kegiatan pembelajaran berbentuk rapat dan diskusi bersama dapat berjalan lebih maksimal. Mengerjakan tugas berkelompok-pun dapat lebih mudah dengan menggunakan Google Doc dimana beberapa siswa dapat menyunting suatu dokumen bersama secara langsung.
\end{abstract}

Kata Kunci: Efektivitas Pembelajaran, Pembelajaran Online, Pandemi Covid-19.

\begin{abstract}
The pandemic Covid-19, which requires everyone, including students to do activities at home, it is easier because of technological advances. The most influential technology in education today is the Internet. The internet allows teachers to provide learning materials without having to meet in person. Teachers can upload learning materials for later access by students. Several internet-based applications and sites are also commonly used by teachers and students to hold face-to-face classes via Whatsapp video calls, Google Clasroom, Zoom Meetings and other online media. Apart from teaching and learning activities, internet-based technology can also be used to support student productive activities. Due to this work from home policy, student activities such as organizations, committees, clubs and so on are hampered. However, by utilizing internet-based applications and sites such as Google Meet, Zoom, Skype and so on, learning activities in the form of meetings and group discussions can run more optimally. Working on group assignments can be easier by using Google Doc where multiple students can edit a document together directly.
\end{abstract}

Keywords: Learning Effectiveness, Online Learning, Covid-19 Pandemic. 


\section{A. Introduction}

At this time, Corona became the talk of warm. In any hemisphere, corona still dominate the public space. In just a short time, his name became a trending topic, discussed here and there, and reported, in particular in the print and electronic media. Severe Acute Respiratory Syndrome Coronavirus 2 (SARS-COV2) which is known by the name of corona virus is a new type of coronavirus that causes the disease infectious to humans.

Covid-19 is an infectious disease caused by a type of coronavirus that new found. Even though more attack to the elderly, this virus actually can also strike anyone, ranging from infants, children, and adults. Corona Virus this could cause an interruption of the light on the respiratory system, infections of the lungs severe, up to death. Corona Virus Disease 2019 (COVID-19) was first found in the city of Wuhan, China at the end of December 2019. The Virus is transmitted very quickly and has spread almost to all countries, including Indonesia, in just a few months. So WHO on 11 March 2020 sets this outbreak as a global pandemic.

This makes some countries set the policy to impose a lockdown in order to prevent the spread of corona virus. In Indonesia alone, the enforced policy Restrictions on Large-Scale Social (PSBB) to suppress the spread of this virus.Because Indonesia is doing PSBB, then all activities done on the outside of the house should be suspended until the pandemic subsided.

Some local governments decided to apply a policy to dismiss students and began to apply the methods learned by the system online (in a network) or online. Government policy is effectively enforced in some areas of the province in Indonesia on Monday, 16 March 2020, which was also followed by region-the territory of other provinces. But it is not true for some schools in each region. These schools not ready with a system of online learning, which requires learning media such as mobile phones, laptop, or computer.

Learning system online (in the network) is a system of learning without face-to-face directly between teachers and students but it is done through online using the internet network. Teachers should ensure that teaching and learning activities keep running, even though students are at home. The solution, teachers are required to design learning media as innovation by utilizing online media (online).

This is in accordance with the Minister of Education and Culture Republic of Indonesia related to Circular Letter No. 4 Year 2020 on the Implementation of Education Policy in Times of Emergency the Spread of Corona Virus Disease (COVID-19).

The learning system implemented via the personal computer (PC) or laptop connected with internet network connection. The teacher can do the learning together at the same time use the group in social media such as WhatsApp (WA), telegram, instagram, zoom app or other media as learning media. Thus, 
teachers can make sure students follow the learning at the same time, though in different places.

All sectors felt the impact of the corona. The world of education is one of them. Judging from the events around that being the case, both students and parents of students who do not have a mobile phone to support learning activities online this feel of confusion, so the schools join the search for solutions to anticipate this. Some students who do not have mobile learning in groups, so that they do the activity of learning together. Start learning through videocall connected with the teacher concerned, given the questions one by one, until mengapsen through the Voice Note is available in WhatsApp. The materials are also given in the form of a video that lasts less than 2 minutes.

The problems that occur not only on the media system of learning but the availability of quota that requires the cost quite high price for students and teachers to facilitate the needs of online learning. Quota purchased for the internet needs to be jumped and many of the parents of students who are not ready to increase the budget in providing the internet network.

Since the discovery of internet technology, almost everything becomes possible in the world of education. Current students can learn not only anywhere but also anytime with a system of electronic learning. E-learning is now increasingly recognized as one way to address the issue of education and training, both in developed countries and in developing countries, in particular Indonesia. Many people use the term that is different to e-learning but in principle e-learning is learning using electronic services as a tool to help him out.

Preparation before giving the service learning is one of the determining factors in the success of learning, especially in online learning where the distance between pebelajar and pemelajar. On pemberlajaran this pemelajar must know the principles of learning and how pebelajar learn. Tool delivery is not a factor in determining the quality of learning, but rather the design of the subjects to determine the effectiveness of learning. One of the reasons for choosing a learning strategy is to raise meaningful learning.So effective whether or not the learning can be identified through the behavior between the pemelajar and learners. How the response pebelajar to what is conveyed by the learners.

\section{B. Discussion}

\section{The Effectiveness of Online Learning}

The effectiveness of the KBBI is the state of the influential, memorable things, the success of a business or action, things start to entry into force of legislation the shrimp or the regulations.The minister of Education and Culture Republic of Indonesia.

Effectiveness is the range of operations of a program as a system with resources and specific means to meet the objectives and targets without crippling the means and resources and without the pressure that is unnatural to its implementation. In the 
learning required careful planning, creation of learning tools, the selection of strategies, media, techniques, learning model, and evaluation of learning all of it mutually sustaining. The need for the use of the model - the model of effective learning and innovative so that learning can be more varied and runs smoothly. The use of learning model is also adjusted with the material to be taught so that the suitability between both of them and all of the components to be appropriate.

One indicator of the effectiveness of learning is the achievement of a learning objective. The learning objectives are achieved to the maximum then can be said of learning to achieve effectiveness. In addition, the involvement of students actively demonstrate the efficiency of learning. The teaching and learning process is said to be effective if learning can achieve the goals that are expected as well as the student can absorb the lesson and practice it. This also becomes a problem which is very important for students, what they should learn and how the data (quota) that they have, while their parents are on low incomes or of middle class (less able). Until finally such a thing as this is charged to parents who want their children to stay abreast of online learning.

Online learning can not be separated from the internet network. The network connection internet is becoming one of the obstacles faced by students whose place of residence is difficult to access the internet, especially students that his place of residence in rural areas, remote and disadvantaged areas. Even if there are using the cellular network, sometimes the network is not stable, because of the geographical location of which is still far from the reach of cellular signals. It is also a problem that a lot happens to students who take online learning so that it is less optimal implementation.

Crowded various social media that tells the experience of the parents for accompanying the children learn both positive and negative. Like for example it turns out there are parents who get angry often because of get her unruly so that they can not stand and want their child to learn back in school.

These events give awareness to the parents that educate the boy it is not easy, required knowledge and huge patience. So with this incident the parents should be aware of and know how to guide their children in learning. After obtaining this experience it is expected that the parents will learn how to educate their children at home.

We need to realize that the unpreparedness of teachers and students towards online learning is also a problem. The displacement system of the conventional learning to the online system very sudden, without preparation. But all this must be done so that the learning process can run smoothly and students actively participated while in the condition of pandemic Covid-19.

Stuttering online learning indeed appears to look in front of us, not one or two schools, but thorough in some areas in Indonesia. Component-a very important component of the process of online learning (online) need to be improved and repaired. First and foremost is the internet network that is stable, then the device or computer that is qualified,application with the user friendly platform, san socialization online 
that is efficient, effective, continuous, and integrative to the whole stekholder education.

A solution for this problem is that the government must provide the policy by opening a free service online applications in cooperation with the internet provider and the app to help the learning process online. The government must also prepare the curriculum and syllabus permbelajaran-based online. For schools need to do a technical guidance (bimtek) online the process of implementation of online and outreach to parents and students through print media and social media about the procedures for the implementation of online learning in relation to the role and duties.

In the process of learning online, it is important to add messages educative to parents and learners, about the outbreak of a pandemic Covid-19. Thus we find the same learning with face-to-face but online based. The effect is very good, the program is right on target, and the achievement of learning achieved. Some of the teachers at the school admitted that, if online learning is not as effective as learning activities conventional (face-to-face), because some of the material should be described in a direct and more complete. In addition, the material presented online is not necessarily be understood by all students. Based on the experience of teaching online, this system is only effective to give the assignment, and the possibility of the results of the processing task-this task is given when the student will enter, so that is likely to accumulate.

Observe the experience of some teachers, then teachers should also be prepared to use technology in accordance with the times. Teachers must be able to create models and learning strategies in accordance with the character of the students in his school. The use of multiple applications on the online learning is very helpful teachers in the learning process. Teachers should be accustomed to teach by utilizing online media complex that should be packed with effective, accessible, and understood by students.

Thus, teachers are required to design and designing online learning that is lightweight and effective, by utilizing devices or online media that are appropriate and in accordance with the material being taught. Even with online learning will provide a broader opportunity to explore the material that will be taught, but teachers should be able to choose and limit the extent of coverage of the material and the suitable application on the material and the learning methods used.

The most simple things can be done by the teacher can be by utilizing the WhatsApp Group. The application WhatsApp is suitable for students of the online beginners, because the operation is very simple and easily accessible to students. As for teachers online who have a spirit that is, can menngkatkan its ability to use a variety of learning apps online.

But once again, select an application in accordance with the needs of teachers dansiswa itself. Not all applications online learning can be used once only. But should be considered according to the needs of teachers and students, the suitability of the material, limitations of infrastructure devices like network. Not very effective if teachers teach by using the zoom app metting but the network or signal in the region the student lives is not good. 
There is a lesson learned from the world of education in the middle of a pandemic Covid-19, namely learning activities face-to-face with teachers proved to be more effective than online (online). Learning full online, lately a lot cause complaints from learners or parents.

The success of the teacher in learning online in a pandemic situation Covid-19 this is the ability of teachers to innovate, designing, and gathering materials, learning methods, and the application of what according to the material and methods. Creativity is the key to success of a teacher to be able to motivate their students to keep the spirit in learning online (online) and not be a burden psychic.

In addition, the success of online learning during the Covid-19 this depends on the discipline of all parties. Therefore, the school/madrasah in here need to make a scheme with compiled good management in organizing learning system online. This is done by making a schedule is a systematic, structured and simple in order to facilitate communication of parents with the school so her son and daughter studying at home can be monitored for effective.

Thus, online learning as an effective solution in learning at home in order to break the chain of spread Covid-19, physical distancing (keeping safe distance) also be a consideration of choosing the learning. Good cooperation between teachers, students, parents and the school/madrasah be the deciding factor to learning online more effective.

\section{E-Learning}

Methods and learning strategies are now experiencing a shift with the leads on the change of educational paradigm. It is influential on the function of the educator as a facilitator, mediator and motivator in the learning process. Teachers are always considered as the center of learning, but has now been turned into a student as learning itself. One reason, among others, is a factor of the rapid advancement of information technology requires changes in the paradigm of the learning process of all students.

Associated with this form of learning independence in the home, through a circular letter, which there, also there is an overview of the model applied, namely, learning through online or in the network (online). Just go back to the school and educators, want to or do not prepare the solution operational patterns, and applicable related 'learning activities' students for at home. Although, its implementation is not as perfect as kala children are in school. Answer that, for the author, there are two things that can be done:

First, the school must make the concept of 'simple' learning online or in a network (online). Moreover, the climate of the village is minimal with the 'signal' mobile do not become barriers so that children keep learning. The concept of 'simple' learning through online be an alternative, so that parents are not confused, even panic, related to the study guide of each unit of education. The goal is to learn the child is still running despite being at home. Step of the way, the school could 
only hold a short workshop to make the application of online learning. If this is not possible, the teacher should communicate the learning steps through WhatsApp (WA), as a practical way to the material subjects (Maple) fixed reviewed independently by the child during at home.

Second, related to the role of parents during a child's self-learning from home, the main thing is to make sure beforehand, whether there are technical instructions of the teacher subject class guardian, or the association related parent step self-learning from home. If there is, then the function parent in addition to as a controller so that the learning activities given to school run, also be a motivator. Namely, give a positive sense that for the child at home, learning must still be done. The goal is that the child is not being misunderstood, that the 14 day 'holiday' at home does not necessarily 'holiday' is also learning. Because it can so, play, watch television, game, will only be a view that is not productive for the child in the home when it was not done.

If no instructions operational study of the house, creating a familiarity with the create library family is an ideal productive. Can in the living room, a special space of learning, up to a permanent space which is allocated to a personal library. The trick together with set up place display books result family collection as there is in the library in general. Then, a variety of the book collection is arranged according to the theme of the discussion. If it is about education, meaning a row of subrak specialize the book. The goal is to easily searchable up when then family members finish reading will be returned as original.

The success of literacy in the family, for the child in the home, will also be created when a collection of books owned in addition to placed at strategic places. Moreover, coupled with the effort to give information embedded books on the shelves. Could be the theme of the topic or genre of fiction books (novels, poetry, short stories) or non fiction, (education, motivation, scientific field special) and other. The point is, with the patch that will allow a calling, the search, when family members want to enable read as an effort to educate the literacy in the family.

It would be better also, if family members (parents) in addition to store a collection of other people's work also gives a special shelf on her work. In addition to a boast of, the existence of a special rack is also to train self-confidence gave birth to the product of papers in the middle of the lack of to-pede-an acknowledge and display the works themselves. Moreover, if then the other family members imitate to produce the paper. Of course, creating literacy in the family is not limited to discourse. But literacy education also has become a program of well-planned family which is not limited to reading, but rather forwarded in writing, in order to give birth to a product the paper from the environment of basic education, namely the family.

The delivery of content through online can be interactive so that participants learn able to interact with the computer as a medium of learning. As one example of students who use learning electronic media or relationship 
(browsing, chat, vidiocall) through electronic media, in this case computers and the internet will eventually achieve learning outcomes more effective and better than conventional learning.

The use of instructional media in the teaching and learning process is one of the efforts to improve the effectiveness and quality of the learning process that ultimately can improve the quality of student learning outcomes. The use of instructional media in the teaching-learning process has several benefits including: (1) Teaching will attract more students so it can cultivate students ' motivation, (2) teaching Material will be clearer so that students can understand and master the teaching objectives with the good, (3) Methods of teaching will be more varied, (4) Students will be more interaction in learning activities because not only listening to the teacher's explanations but also other activities such as observing, demonstrating, and others.

E-learning as any teaching and learning that uses electronic circuits (LAN, WAN, or the internet) to convey the learning contents, interaction, or guidance. Hartley (2001) describes bahwae E-learningmerupakan a type of learning that allows teaching materials to students by using internet media, intranet or other computer network media. Rosenberg (2001) emphasized that E-learningmerujuk on the use of internet technology to transmit a series of solutions that can improve their knowledge and skills.

E-learning has been to shorten the learning time and make the cost of the study more economical. E-learning facilitate interaction between learners with the material or subject matter, of learners with the teacher or the instructor and fellow learners. Learners can share information and can access learning materials at any time and repeatedly, with the condition that such learners can further solidify their control of the learning material. In E-learning, which takes the role of the teacher is the computer and electronic guidelines that are designed by "content writer", Elearning designers and computer programmers.

E-Learning is a method of internet-based learning or online learning that should be undertaken all students to students in Indonesia even the whole region of the world that are exposed to the pandemic Covid-19 to connect the process of learning face-to-face is constrained due to social distancing or not clustered to help prevent the spread of Covid-19.In Indonesia, the system of e-learning is no longer something that is foreign, just not all the school ever implement this system, especially schools in rural areas

\section{Conclusion}

The impact of the spread of corona virus or commonly known as Covid-19 is huge in the world, including Indonesia. Various aspects of life has been affected due to the presence of this virus, ranging from health, security, social, economy to education. The impact of corona virus is the one that requires the people of Indonesia now to change and re-adjust their lifestyle. The adjustment was done 
with various ways, such as the implementation of social distancing, physical distancing, the lockdown region and work from home. Education in Indonesia, as already alluded to above, did not escape from the impact of the spread of corona virus. Because of the spread of corona virus from one person to the other, then the policy of social distancing was imposed in order to avoid crowds of people which can accelerate the possibility of the spread of corona virus. To implement this policy, schools and colleges 'dismiss' students. They are encouraged to continue learning at home during the pandemic is through online classes. Due to these circumstances, many students feel that the activities they are learning at home is limited. The activities of the talent development, communities, organizations, hobbies, interests and talents that they do in school and the campus is now hampered. They felt the productivity of the non-academic they declined. Even some students also feel it is a bad impact on the productivity of their academic. However, this is not entirely true. A lot of things that can be done in the student houses to keep and increase their productivity in the field of academic and nonacademic.

\section{References:}

Al-Tabany, T. I. B, Designing the Learning Model is Innovative, Progressive, and Contextual, Jakarta: Kencana,2017.

Dewi, W. A. F, The impact of Covid 19 Against the Implementation of Online Learning in the Elementary School. Educational, Journal Of Education, Vol 2 No 1, 2020.

Firdaus, A. M, The effectiveness of learning mathematics through the application of model cooperative learning type snowball throwing, BETA: a Journal of Tadris Mathematics, Vol 9. No 1, 2016.

The Word, \& Rahman, S. R, Online learning in the Midst of a Pandemic Covid-19, IJES: Indonesian Journal Of Education, Science, Vol 2 No 2020.

H. Tandra, Corona Virus New Covid-19 Recognize, Prevent, Protect Yourself $\mathcal{E}$ Others, Yogyakarta: Rapha Publishing, 2020.

Munir, Distance learning Based on Information Technology and Communication. (Bandung: Alfabeta, 2012).

Prawiradilaga, Salma, et al. Mosaic Technology Education: E - Learning, Jakarta: Prenadamedia Group, 2016.

Purwanto, A, Rudy Pramono, Masduki Asbari, Priyono Budi Santoso, Lakshmi Mayesti, Rahmawati, Training And Development of Distance Education based on Digital Class Platform Edmodo.

Rohmawati, A, The Effectiveness Of Learning, Journal Of Early Childhood Education, Vol. 9, No. 1, 2015.

Usman Roin, 50 Status Inspiring, Semarang: YAPAPB, 2020. 
Usman, M. H., \& Aswar, Covid-19 In The Course Of The End Of Time: Cause, Impact And Recommendation Of The Sharia To Deal With It, Bustanul Fugqoha: Journal Of The Field Of Islamic Law, Vol 1, No 2, 2020.

Wijayanti, Choi Chi Hyun, Ratna Setyowati Putri, Exploratory Studies the Impact of the Pandemic COVID-19 Against the Process of Online Learning in the Elementary School, Journal of Education, Psychology and counseling, Vol. 2, No. 1, 2020.

Jerusalem, M. R, \& et al, Design and Implementation of Distance Learning System At the Study Program Computer Systems, Journal of Technology and Computer Systems, Vol. 3, No. 4, 2020. 